\title{
MUNKAHELYI TÉNYEZŐK ÉS PSZICHÉS JÓL-LÉT AZ OKTATÁS ÉS KULTÚRA TERÜLETÉN DOLGOZÓ NÖK KÖRÉBEN
}

\author{
NECULAI KRISZTINA* - SALAVECZ GYÖNGYVÉR - \\ STAUDER ADRIENNE - KOPP MÁRIA
}

Semmelweis Egyetem, Magatartástudományi Intézet, Budapest

(Beérkezett: 2006. április 18.; elfogadva: 2006. április 28.)

\begin{abstract}
Jelen kutatás célkitúzése a pszichés jól-lét kapcsolatának elemzése öt munkahelyi stressztényezôvel: az alacsony munkahelyi kontrollal, a munkatársi társas támogatottság hiányával, a munkával kapcsolatos bizonytalansággal, valamint a munkával és a főnökkel való elégedetlenséggel. Módszerek: Elemzéseinket a Hungarostudy 2002 országos reprezentatív felmérés egy almintáján végeztük, azon nók körében, akik az oktatás és kultúra területén dolgoztak $(n=451)$. A pszichológiai jól-létet négy mutató mentén vizsgáltuk: a depressziós tünetegyüttes, a vitális kimerültség, a szorongás, valamint az általános jól-lét mentén. Az adatok statisztikai feldolgozásához lépésenkénti lineáris regressziót alkalmaztunk. Eredmények: Eredményeink szerint a munkahelyi kontroll az általános jól-lét védő tényezőjének bizonyult, míg a főnökkel való elégedetlenség vitális kimerültséggel, depressziós tünetegyüttessel és alacsonyabb általános jól-léttel társult. A munkával való elégedetlenség mind a négy elemzett mentális jól-lét indikátor alakulását bejósolta. A munkahelyi biztonságérzet alacsony szorongással és magas általános jól-lét pontszámmal járt együtt. Nem várt módon, a munkatársi támogatottság és az általános jól-lét között fordított irányú együttjárást találtunk. Következtetések: A kutatás eredményei részben alátámasztják a létező ismereteket a munkahelyi tényezók és a mentális egészség közötti kapcsolatot illetően. Az ilyen témájú vizsgálatok fontos kiindulási pontot képezhetnek a munkával kapcsolatos stresszt kezelô programok megtervezésében és bevezetésében.
\end{abstract}

Kulcsszavak: munkahelyi stresszorok, mentális jól-lét, nók

\footnotetext{
* Levelezô szerzô: Neculai Krisztina, Semmelweis Egyetem, Magatartástudományi Intézet. 1089 Budapest, Nagyvárad tér 4. E-mail: neculaikrisztina@freemail.hu
} 
Az elmúlt három évtized kutatásainak eredményeképpen ma már széles körben elfogadott, hogy a rossz munkahelyi körülmények rizikótényezőt jelentenek az alkalmazottak testi és lelki egészségére nézve. A témában folytatott kutatásokban különös figyelmet fordítottak olyan munkahelyi stresszforrások vizsgálatára, mint az alacsony munkahelyi kontroll, a munkatársi és vezetôi támogatás hiánya, a munkával való elégedetlenség és a munkahelyi bizonytalanság.

A munka feletti kontroll és a munkahelyi társas támogatottság kapcsolatát az egészséggel leggyakrabban a Karasek-féle követelmény-kontroll-támogatás modell (Karasek 1979; Karasek és Theorell 1990) kereteiben vizsgálták. A vizsgálatok alapján kiderült, hogy a modell komponensei igen jó előrejelzói a kardiovaszkuláris megbetegedéseknek (Kristensen 1995; Schnall és mtsai 1994; Theorell és Karasek 1996). Van der Doef és Maes (1999) összefoglaló tanulmánya szerint a kontroll és a társas támogatás szerepe a pszichológiai jól-lét alakulásában még nem egyértelmúen tisztázott. Úgy tûnik, a társas támogatás és a munka feletti kontroll bizonyos körülmények vagy személyiségtényezók jelenléte esetében jelentenek védőhatást a pszichológiai jól-létre nézve.

A munkával való elégedetlenség jelentôs stresszforrásnak számít: kimutatták kapcsolatát a kiégéssel (Pikó 2006), a pszichés distresszel (Heslop és mtsai 2002), az élettel való elégedetlenséggel, az alacsony pozitív affektivitással, az énkép romlásával (Kohan és O'Connor 2002).

A globalizálódó világban a piaci versenyképesség megórzésének érdekében számos vállalat és iparág kényszerül arra, hogy leépítéseket vagy átstrukturálásokat végezzen, így a munkával kapcsolatos bizonytalanság szinte állandó problémát jelent. Longitudinális vizsgálatok igazolják, hogy a munkával kapcsolatos bizonytalanság növeli a szívinfarktus bekövetkezésének (Lee és mtsai 2004), a kisebb fertôző vírusos megbetegedéseknek (Mohren és mtsai 2003) és az enyhe pszichiátriai tünetek elófordulásának esélyét (Swaen és mtsai 2004). Egy, a munkahelyi bizonytalanság következményeit vizsgáló metaanalízis szerint a munkával kapcsolatos bizonytalanság az egészségi mutatókon kívül az alkalmazottaknak a munkájukról és szervezetükrôl alkotott attitúdjeit is negatívan befolyásolta (Sverke és mtsai 2002).

Magyar kutatások is alátámasztják a munkahelyi pszichoszociális környezet, valamint a testi és lelki megbetegedések közötti kapcsolatot. Az ilyen témájú vizsgálatoknak igen nagy részét végezték a humán szféra alkalmazottai körében, elsôsorban orvosok, orvosnók (Győrffy és Ádám 2004a, 2004b, Győrffy és mtsai 2004), nővérek (Pikó 1999, 2001, 2003, 2006; Sasváriné és Kóczán 2001) és pedagógusok (Petróczi és mtsai 1999) között. 
A munkahelyi tényezók és a pszichoszomatikus tünetek közötti kapcsolat vizsgálata különös figyelmet érdemel nók körében. Számos tanulmány szerint a nók átlagosan magasabb munkahelyi stresszról számolnak be, mint a férfiak (Karasek és Theorell 1990; Karasek és mtsai 1998; Roxburgh 1996). Annak ellenére, hogy nók körében magasabb a pszichés panaszok prevalanciája is (Denton és mtsai 2004; Kopp és mtsai 2006a; Lahelma és mtsai 1999; Macintyre és mtsai 1996), férfiak körében nagyobb számú olyan kutatást végeztek, ami azoknak a munkahelyi tényezóknek a maghatározására irányult, amelyek a mentális jól-létet befolyásolják (Hall 1989, Williams és Kurina 2002).

Magyarországon Kopp és mtsai (2006b) elemezték a különbözó ágazatokban dolgozó nók életminóségét, és azt találták, hogy az oktatás és kultúra területén dolgozók valamennyi életminóség-mutató tekintetében a legjobb helyzetben voltak. Az életminóség kapcsolatát a munkahelyi pszichoszociális környezettel az említett mintán még nem vizsgálták. Jelen kutatás azt a célt túzte ki, hogy megvizsgálja, hogy az oktatás és kultúra területén alkalmazottak körében a pszichés jól-lét mutatóit milyen mértékben határozzák meg olyan, munkával kapcsolatos tényezók, mint a munkahelyi kontroll, a munkatársi társas támogatottság, a munkával kapcsolatos bizonytalanság, a munkával és a fônökkel való elégedetlenség.

A szakirodalomban közölt eredmények alapján azt feltételezzük, hogy a munka feletti kontroll, a munkahelyi társas támogatottság, a munkahelyi biztonságérzet védố tényezóje lesz a pszichés jól-létnek, míg a munkával és a fónökkel való elégedetlenség rosszabb mentális egészséggel fog együtt járni.

\section{MÓDSZEREK}

\section{Minta}

Vizsgálatunk mintáját a Hungarostudy 2002 országos reprezentatív felmérés egy almintája képezi. Az említett felmérés keretében 2002-ben a Magyar Védónói Hálózat munkatársai 12668 személyt kerestek meg otthonukban, és kérdezték meg demográfiai jellemzőikról, testi és pszichés egészségükról, az egészségügyról alkotott véleményükról, pszichoszociális védố és kockázati tényezóikról. A minta korra, nemre és kistérségre reprezentálta Magyarország felnôtt lakosságát. A teljes minta esetén a válaszadási ráta közel $83 \%$ volt.

Jelen tanulmány elemzései az említett minta egy részére terjednek ki, nevezetesen azokra a nókre, akik az oktatás vagy kultúra területén dolgoztak, és akik gazdaságilag aktívak voltak a felmérés idején. E három kritériumnak 451 személy felelt meg. 


\section{A vizsgálatban szereplố változók}

Az alábbiakban ismertetjük a Hungarostudy 2002 kérdőív azon kérdéseit és skáláit, amelyek a jelen vizsgálat elemzéseiben szerepelnek.

A munkával kapcsolatos biztonságérzet mérésére a Stressz és megbirkózás kérdőív (Rahe és Tolles 2002) következő itemét alkalmaztuk: „Örülök, hogy biztos munkám van." A válaszadás a következő háromfokú skála segítségével történt: 0 - nem, 1 - igen, 2 - igen, mindig.

A munkával és fônökkel való elégedettséget szintén a Stressz és megbirkózás kérdőív (Rahe és Tolles 2002) állításaival mértük a következóképpen: „Elégedetlen vagyok a munkámmal”, illetve „Elégedett vagyok a főnökömmel”. A válaszadás háromfokú skálán történt.

A munkahelyi kontrollt a következó kérdéssel mértük: „Tudja befolyásolni, ami a munkacsoportjában történik?" A megkérdezettek a következố négy variáns közül választották ki a rájuk leginkább jellemzốt: egyáltalán nem, keveset, közepesen, nagy mértékben.

A munkatársi társas támogatottság mérésére a Caldwell-féle társas támogatottság kérdőív (Caldwell és mtsai 1987) következô négy válaszos iteme szolgált: „Nehéz élethelyzetben mennyire számíthat az alábbiak segítségére? (...) munkatárs".

A pszichés életminóséget négy mutató mentén elemeztük.

A depressziós tünetegyüttes mérésére a Rövidített Beck Depresszió Skálát (Beck és mtsai 1961; Beck és Beck 1972; Kopp és mtsai 1998; Rózsa és mtsai 2001) alkalmaztuk. A méróeszköz kilenc állítást tartalmaz a következó jellemzókkel kapcsolatban: szociális visszahúzódás, döntésképtelenség, alvászavar, fáradékonyság, túlzott aggódás a testi tünetek miatt, munkaképtelenség, pesszimizmus, elégedetlenség, örömképesség hiánya, önvádlás (Kopp 1994, 147). A kérdőív rövidített változatának válaszai: 1 - egyáltalán nem jellemzó, 2 - alig jellemzó, 3 - jellemzó, 4 - teljesen jellemzô. A Hungarostudy 2002 felmérés mintáján a skála Cronbach $\alpha$ értéke 0,85, ami az itemek szoros együttjárására utal (Rózsa és mtsai 2006).

A vitális kimerültség mérésére a Maastricht Vitális Kimerültség Skála (Kopp és mtsai 1998, Falger és Appels 1982) rövidített változata szolgált. A méróeszköz vizsgálatunkban használt változata öt itemet tartalmaz, és a gyakori fáradtságra, a gyengeség érzésére, kedvetlenségre, ingerlékenységre, testi gyengeségre kérdez rá. A vizsgálati személyek igennel vagy nemmel jelölték, hogy jellemzik-e ôket az állításokban foglaltak. Az öt tétel esetén számolt Cronbach $\alpha$ érték a Hungarostudy 2002 felmérésben 0,78 volt (Rózsa és mtsai 2006). 
A szorongást a Kórházi Szorongás Skála (Zigmond és Snaith 1983) hét itemével mértük, melyek esetében a válaszadás egy négyfokú Likert-skálán történik. A méróeszköz megbízható, az országos mintán a rövidített skála Cronbach $\alpha$ mutatója 0,82 volt (Rózsa és mtsai 2006).

Az általános jól-létet a WHO általános jól-lét skála (Bech és mtsai 1996, Rózsa és mtsai 2006) öt állításával mértük. A kitöltő személyek négyfokú skálán jelölték be, hogy az utolsó két hétben mennyire érezték magukat vidámnak és jókedvúnek, nyugodtnak és ellazultnak, aktívnak és élénknek, ébredéskor frissnek és pihentnek, illetve, hogy a napjaik mennyire voltak tele számukra érdekes dolgokkal. Az öt itemre számolt Cronbach a 0,84 volt a Hungarostudy 2002 országos felmérés mintáján (Rózsa és mtsai 2006).

Elemzéseinkbe két demográfiai változót, az életkort és az iskolai végzettséget is beemeltünk, hogy ezek hatására kontrolláljunk. A hat kategóriás iskolai végzettség változóból dummy változót hoztunk létre. Nullával kódoltuk a diplomával nem rendelkezóket, míg 1-sel jelöltük a diplomás alkalmazottakat. Az életkor, mint folytonos változó szerepelt.

\section{Statisztikai elemzések}

Az adatok statisztikai elemzése az SPSS 10.0 programmal történt. A demográfiai és a munkahelyi tényezók és a pszichés egészség közötti kapcsolat meghatározására korrelációs számítást, majd lépésenkénti lineáris regressziót alkalmaztunk. A regressziós modellek első lépésében a két demográfiai változót, a kort és az iskolai végzettséget emeltük be, annak érdekében, hogy ezek hatására kontrolláljunk. Az öt, munkával kapcsolatos változó a második lépésben került be a négy függố változónak megfelelő modellbe. Analíziseinkben a $p</=0,05$-ös szignifikanciaküszöböt használtuk.

\section{EREDMÉNYEK}

A minta szociodemográfiai jellemzóit az 1. táblázatban mutatjuk be. A vizsgálatban részt vevő személyek túlnyomó része felsőfokú végzettséggel rendelkezett, szakalkalmazottként dolgozott és házas volt. A minta közel 40\%-ának havi nettó jövedelme nem haladta meg a 2002. évi 50000 forint nagyságú minimálbért, 94,3\%-é pedig az akkori diplomás minimálbért. 
1. táblázat. A minta szociodemográfiai jellemzói

\begin{tabular}{lr} 
Változók & $\%$ \\
\hline Iskolai végzettség & 0,7 \\
\hline Kevesebb mint 8 általános & 6,9 \\
8 általános & 10,2 \\
Szakmunkásképző & 6,5 \\
Szakközépiskolai érettségi & 8,0 \\
Gimnáziumi érettségi & 67,7 \\
\hline Fóiskolai vagy egyetemi diploma & \\
\hline Munka jellege & 0,2 \\
\hline Nincs foglakozása, soha nem dolgozott & 2,0 \\
Segédmunkás & 7,9 \\
Betanított munkás & 6,5 \\
Szakmunkás & 2,5 \\
Nem diplomás vezetó, irányító & 58,6 \\
Szakalkalmazott & 6,8 \\
Ügyviteli dolgozó & 15,5 \\
Diplomás vezetó & \\
\hline Családi állapot & 14,4 \\
\hline Nótlen, hajadon, egyedülálló & 65,0 \\
Házas, házastársával együtt él & 2,4 \\
Házas, házastársával nem él együtt & 9,3 \\
Elvált & 5,3 \\
Özvegy & 3,5 \\
Élettársi kapcsolat & 38,5 \\
\hline Jövedelem & 55,8 \\
\hline 50 ezer Ft vagy annál kevesebb & 4,1 \\
51-100 ezer Ft között & 0,7 \\
101-150 ezer Ft között & 0,5 \\
151-200 ezer Ft között & 0,2 \\
201-250 ezer Ft között & 0,2 \\
251-300 ezer Ft között & - \\
301-500 ezer Ft között & \\
501 ezer Ft és afölött & \\
& \\
\hline & \\
\hline
\end{tabular}

A 2. táblázatban tüntettük fel az elemzésekben szereplô változók átlagát, szórását, valamint a Pearson-féle korrelációs együtthatókat. Az életkor növekedésével emelkedett a Beck-féle depresszió és vitális kimerültség pontszám, és csökkent az általános jól-lét pontszám. Az alacsony munkahelyi kontroll emelkedett depressziós tünetegyüttes, nagyobb vitális kimerültség és alacsonyabb általános jól-lét pontszámmal társult. Gyenge összefüggés mutatkozott a munkával való elégedetlenség és a pszichés jól-lét elemzett négy mutatója között. A munkával kapcsolatos biztonság- 
2. táblázat. Az elemzésekben szereplő változók átlaga, szórása és korrelációs mátrixa

\begin{tabular}{|l|c|c|c|c|c|c|c|c|c|c|c|c|}
\hline Változó & Átlag & SD & 1. & 2. & 3. & 4. & 5. & 6. & 7. & 8. & 9. & 10. \\
\hline 1. Életkor & 42,50 & 9,87 & 1,00 & & & & & & & & & \\
\hline $\begin{array}{l}\text { 2. Munkahelyi } \\
\text { kontroll }\end{array}$ & 1,82 &, 98 &,- 06 & 1,00 & & & & & & & & \\
\hline $\begin{array}{l}\text { 3. Munkával való } \\
\text { elégedetlenség }\end{array}$ &, 48 &, 62 &,- 03 &, 02 & 1,00 & & & & & & & \\
\hline $\begin{array}{l}\text { 4. Munkával kapcso- } \\
\text { latos biztonságérzet }\end{array}$ & 1,78 &, 51 &, 06 &, $20^{* * *}$ &, 00 & 1,00 & & & & & & \\
\hline $\begin{array}{l}\text { 5. Elégedetlenség } \\
\text { a fónökkel }\end{array}$ &, 50 &, 63 &, 00 &, 07 &, $21^{* * *}$ &, 03 & 1,00 & & & & & \\
\hline $\begin{array}{l}\text { 6. Munkatársi társas } \\
\text { támogatottság }\end{array}$ & 1,74 &, 84 &,- 04 &, $22^{* * *}$ &,- 08 &, $14^{* *}$ &, 01 & 1,00 & & & & \\
\hline $\begin{array}{l}\text { 7. Depressziós } \\
\text { tünetegyüttes }\end{array}$ & 4,85 & 6,17 &, $20^{* * *}$ &,$- 12^{*}$ &, $11^{*}$ &,- 02 &, 09 &,- 01 & 1,00 & & & \\
\hline 8. Vitális kimerültség & 2,14 & 2,09 &, $22^{* * *}$ &,$- 13^{* *}$ &, $12^{*}$ &,- 08 &, 09 &,- 07 &, $49^{* * *}$ & 1,00 & & \\
\hline 9. Szorongás & 4,82 & 3,80 &, 08 &,- 06 &, $10^{*}$ &,- 09 &, 05 &, 03 & $, 60^{* * *}, 53^{* * *}$ & 1,00 & \\
\hline 10. Általános jól-lét & 8,67 & 3,46 &,$- 15^{* *}$ &, $18^{* * *}$ &,$- 10^{*}$ &, $12^{*}$ &,- 07 &,- 03 &,$- 34^{* * *}-, 48^{* * *}$ &,$- 44^{*}$ & 1,00 \\
\hline
\end{tabular}

${ }^{*} p<0,05,{ }^{* *} p<0,01,{ }^{* * *} p<0,001$

érzet magas általános jól-lét pontszámmal járt együtt. A pszichés jól-lét mutatói és a főnökkel való elégedettség, illetve a munkatársi társas támogatottság között nem találtunk összefüggést.

A 3. táblázat tartalmazza a lineáris regresszióanalízis eredményeit. Korra és iskolai végzettségre való kontrollálás után a depressziós tünetegyüttes a munkával és a főnökkel való elégedetlenséggel mutatott összefüggést. A két demográfiai változó és a munkával kapcsolatos tényezók a Beckféle depresszió pontszám varianciájából 8,3\%-ot magyaráztak.

A vitális kimerültséget tekintve a magas életkor, a munkával és a fónökkel való elégedetlenség jelentett rizikótényzót. A munkával kapcsolatos stressztényezókkel 5,2\%-ot, a demográfiai tényezóket is figyelembe véve 10,2\%-ot sikerült magyarázni a vitális kimerültség varianciájából.

$\mathrm{Az}$ alacsony iskolai végzettség, a munkával való elégedetlenség és a munkahelyi biztonságérzet hiánya magasabb szorongásszinttel járt együtt.

Míg az alacsony életkor, a munkahelyi kontroll és a munkával kapcsolatos biztonságérzet az általános jól-létnek védó faktorai voltak, addig a munkával való elégedetlenség veszélyeztetó tényezóként szerepelt. Nem várt módon, az alacsony általános jól-lét jobb munkahelyi társas támogatottsággal járt együtt. Ezen tényezók együttesen az általános jóllét pontszám varianciájának $12 \%$-át magyarázták. 
3. táblázat. A lineáris regresszió analízis eredményei: a demográfiai és munkahelyi tényezók és a pszichés jól-lét mutatói közötti kapcsolat

\begin{tabular}{|c|c|c|c|c|}
\hline \multirow[t]{2}{*}{ Munkahelyi tényezók } & \multicolumn{4}{|c|}{ Standardizált $ß$ együtthatók } \\
\hline & \begin{tabular}{|c|} 
depressziós \\
tünet- \\
együttes
\end{tabular} & $\begin{array}{c}\text { vitális } \\
\text { kimerültség }\end{array}$ & szorongás & $\begin{array}{c}\text { általános } \\
\text { jól-lét }\end{array}$ \\
\hline \multicolumn{5}{|l|}{ I. lépés } \\
\hline Életkor & $0,17 * * *$ & $0,20^{* * *}$ & 0,07 & $-0,16^{* *}$ \\
\hline Iskolai végzettség & $-0,11^{*}$ & $-0,07$ & $-0,10^{*}$ & 0,05 \\
\hline$R^{2}(\%)$ & $4,8^{* * *}$ & $5,0^{* * *}$ & $1,7^{*}$ & $3,3^{* *}$ \\
\hline \multicolumn{5}{|l|}{ II. lépés } \\
\hline Életkor & $0,17 * * *$ & $0,20 * * *$ & 0,08 & $-0,17^{* * *}$ \\
\hline Iskolai végzettség & $-0,13^{*}$ & $-0,08$ & $-0,12^{*}$ & 0,03 \\
\hline Munkahelyi kontroll & $-0,06$ & $-0,08$ & $-0,02$ & $0,17^{* *}$ \\
\hline Munkával való elégedetlenség & $0,12^{*}$ & $0,13^{* *}$ & $0,11^{*}$ & $-0,10^{*}$ \\
\hline Munkahelyi biztonságérzet & $-0,02$ & $-0,06$ & $-0,09^{*}$ & $0,10^{*}$ \\
\hline Elégedetlenség a fónökkel & $0,10^{*}$ & $0,09^{*}$ & 0,04 & 0,09 \\
\hline Munkatársi társas támogatottság & 0,04 & $-0,03$ & 0,06 & $-0,10^{*}$ \\
\hline$\Delta R^{2}(\%)$ & 3,5 & 5,2 & 2,9 & 6,9 \\
\hline$R^{2}(\%)$ & $8,3^{* * *}$ & $10,2^{* * *}$ & $4,6^{* *}$ & $10,2^{* * *}$ \\
\hline F változás & $4,74^{* * *}$ & $6,75^{* * *}$ & $2,92^{*}$ & $6,10^{* * *}$ \\
\hline
\end{tabular}

${ }^{*} p<0,05,{ }^{* *} p<0,01,{ }^{* * *} p<0,001$

\section{MEGBESZÉLÉS}

Jelen kutatásban azt a célt túztük ki, hogy megvizsgáljuk az oktatás és a kultúra területén dolgozó nók mintáján, hogy a mentális jól-lét indikátorai milyen mértékben járnak együtt a munkával kapcsolatos stressztényezôkkel. Feltételezésünk az volt, hogy a munkahelyi körülmények negatívabb megítélése rosszabb mentális egészséggel fog társulni.

Várakozásainknak megfelelóen, azt találtuk, hogy korra és iskolai végzettségre való kontrollálás után a munkával való elégedetlenség a lelki egészség valamennyi mutatójával összefüggést mutatott, míg a fónökkel való elégedetlenség a depressziós tünetegyüttessel és a vitális kimerültséggel járt együtt. Mivel e két munkahelyi tényező mérése egy-egy itemmel történt, nem áll rendelkezésünkre információ arra vonatkozóan, hogy az oktatás és kultúra területén dolgozó nók munkájuk melyik aspektusaival elégedetlenek. Eredményeink összhangban vannak Van der Doef és Maes (1999) azon megfigyelésével, miszerint a munkával való elégedettség a pszichés egészség legjelentôsebb prediktorai között szerepel.

A munkával kapcsolatos biztonságérzet az elemzett szektorban az 
alkalmazottak igen nagy százalékát jellemezte. A megkérdezett nók 82,2\%-a nyilatkozta azt, hogy örül, hogy biztos munkája van. Ez a tényezố védó faktorként szerepelt a szorongással szemben és magasabb általános jól-léttel járt együtt. Több, e témájú vizsgálat eredményeinek áttekintése után Ferie és mtsai (2003) hangsúlyozzák, hogy a munkahelyi bizonytalanság minden általuk elemzett tanulmányban magasabb pszichés morbiditással társult.

Vizsgálatunkban a munkahelyi kontroll bizonyult az általános jól-lét legeróteljesebb prediktorának, a többi elemzett lelki egészség mutatóval azonban nem mutatott összefüggést. Számos vizsgálat igazolja, hogy a nók átlagosan alacsonyabb munka feletti kontrollal rendelkeznek, mint a férfiak (Denton és mtsai 2004; Hall 1989; Karasek és Theorell 1990; Karasek és mtsai, 1998; Li és Cho 2006). Ezekból a vizsgálatokból ugyanakkor az is kitúnik, hogy nóknél az alacsony munkahelyi kontroll kevésbé veszélyeztetố tényezó a mentális egészségre nézve, mint férfiaknál (Denton és mtsai 2004; Van der Doef és Maes 1999).

Míg az alacsony munkahelyi kontroll inkább a férfiakat veszélyezteti, addig a vizsgálatok szerint a nók pszichés vulnerábilitása a munkahelyi társas támogatással szemben nagyobb (Denton és mtsai 2004; Li és Cho 2006). Vizsgálataink nem támasztották alá ezeket az eredményeket, a regressziós analízisben e hipotézissel ellentétes eredményekhez jutottunk. Az alacsony általános jól-lét pontszám magas munkatársi támogatással társult. Bár vizsgálatunk keresztmetszeti elrendezése nem tesz lehetôvé okságra vonatkozó következtetéseket, valószínúsíthetô, hogy a vizsgálatban részt vevố nók rossz közérzet esetén nagyobb társas támogatást kapnak kollegáiktól.

Vizsgálatunk hiányosságai közül elsóként említjük azt, hogy a munkahelyi tényezók mérése mind az öt esetben egy itemmel történt, ami problémát jelenthet a mérés pontosságát illetóen. Másodszor: vizsgálatunk keresztmetszeti elrendezése nem teszi lehetôvé oksági viszonyok elemzését a munkahelyi tényezók és az egészség közötti kapcsolatban. Fontosnak tartjuk ezért a tanulmány hipotéziseit longitudinális vizsgálatban is elemezni. Harmadszor: torzító tényezó adódhat abból, hogy a használt mérốeszközök önjellemzôsek. Számos szerző (Cox és mtsai 2000; Joksimovic és mtsai 2002) ajánlja, hogy kontrolláljuk a hangulat hatását a munka pszichoszociális jellemzói és az egészség közötti kapcsolatra, bár ebben a kérdésben még komoly viták folynak (Karasek és mtsai 1998).

Következtetésképpen elmondhatjuk, hogy eredményeink hozzáadhatók a korábbi ismeretekhez, melyek szerint a munkahelyi tényezók kockázatot jelentenek az alkalmazottak lelki egészségének romlására nézve. A vizsgálat eredményei felhívják a kutatók és a gyakorló szakembe- 
rek figyelmét arra, hogy fontos bóvítenünk az ismereteinket a munkastressz és az egészségi mutatók kapcsolatát illetôen, hisz ezek képezik a munkastressz menedzsment programok megtervezésének és bevezetésének alapját. További vizsgálatokban fontos a mentális egészséget befolyásoló más munkahelyi tényezóket feltérképezni, valamint más pszichoszomatikus betegségek kapcsolatát elemezni a munkahelyi pszichoszociális környezettel. Mivel sok esetben a munkahelyi stresszorok intenzitása nehezen csökkenthetô, fontos további kutatásokban fényt deríteni azokra az egyéni tényezókre, amelyek a munkával összefüggó stressz egészségre gyakorolt káros hatását csökkenthetik.

\section{Irodalom}

Bech, P., Gudex, C., Staehr-Johansen, K. S. (1996): The WHO (Ten) Well-Being Index: validation in diabetes. Psychotherapy and Psychosomatics, 65 (4): 183-190.

Beck, A. T., Beck, R. W. (1972): Shortened version of BDI. Post. Grad. Med., 52: 81-85.

Beck, A. T., Ward, C. H., Mock J., Erbaugh J. (1961): An inventory for measuring depression. Archives of General Psychiatry, 4: 561-571.

Caldwell, R. A. Pearson, J. L. Chin, R. J. (1987): Stress-moderating effects: social support in the context of gender and locus of control. Personality and Social Psychology Bulletin, 13 (1): 5-17.

Cox, T., Griffiths, A. J., Rial-Gonzalez, E. (2000): Research on work-related stress. Report to the European Agency for Safety and Health at Work. Office for Official Publications of the European Communities, Luxembourg. http://agency.osha.eu.int/publications/ reports/stress. Elérés: 2005. március 11.

Denton, M., Prus, S., Walter, V. (2004): Gender differences in health: a Canadian study of the psychosocial, structural and behavioural determinants of health. Social Science $\mathcal{E}$ Medicine, 58 (12): 2585-2600.

Falger, P., Appels, A. (1982): Psychological risk factors over the life course of myocardial infarction patients. Advances in Cardiology, 29: 132-139.

Ferrie, J. E., Shipley, M. J., Stansfeld, S. A., Smith, G. D., Marmot, M. (2003): Future uncertainty and socioeconomic inequalities in health: the Whitehall II study. Social Science \& Medicine, 57 (4): 637-646.

Győrffy Zs., Ádám Sz. (2004a): Az orvosnói hivatás magatartástudományi vizsgálata. Mentálhigiéné és Pszichoszomatika, 5 (1): 27-53.

Győrffy Zs., Ádám Sz. (2004b): Az egészségi állapot, a munkastressz és a kiégés alakulása az orvosi hivatásban. Szociológiai Szemle, 3: 107-127.

Győrffy Zs., Mészáros E., Ádám Sz., Kopp M. (2004): Az egészségügyben dolgozó nók gyermekvállalással és terhességgel kapcsolatos mutatói országos reprezentatív minta alapján. Mentálhigiéné és Pszichoszomatika, 5 (4): 321-333.

Hall, E. M. (1989): Gender, work control, and stress: a theoretical discussion and an empirical test. Int. J. Health. Serv., 19 (4): 725-45.

Heslop, P., Smith, G. D., Metcalfe, C., Macleod, J, Hart, C. (2002): Change in job satisfaction, and its association with self-reported stress, cardiovascular risk factors and mortality. Social Science \& Medicine, 54 (10): 1589-1599. 
Joksimovic, L., Starke, D., vd Knesebeck, O., Siegrist, J. (2002): Perceived work stress, overcommitment and self-reported muskuloskeletal pain: a cross-sectional investigation. International Journal of Behavioural Medicine, 9 (2): 122-129.

Karasek, R. A. (1979): Job demands, job decision latitude, and mental strain: Implications for job redesign. Administrative Science Quarterly, 24: 285-308.

Karasek, R., Theorell, T. (1990): Healthy Work. Stress, Productivity, and the Reconstruction of Working Life. Basic Books, Harper Collins Publishers.

Karasek, R. A., Brisson, C., Kawakami, N., Houtman, I., Bongers, P. Benjamin A. (1998): The Job Content Questionnaire (JCQ): An instrument for internationally comparative assessments of psychosocial job characteristics. Journal of Occupational Health Psychology, 3 (4): 322-355.

Kohan, A., O'Connor, B. P. (2002): Police officer job satisfaction in relation to mood, wellbeing, and alcohol consumption. The Journal of Psychology, 136 (3): 307-318.

Kopp M. (1994): Orvosi pszichológia. Az egészséglélektan és a magatartásorvoslás alapjai. SOTE, Budapest.

Kopp, M., Falger, P., Appels, A., Szedmák S. (1998): Depression and vital exhaustion are differentially related to behavioural risk factors for coronary heart disease. Psychosomatic Medicine, 60 (6): 752-758.

Kopp M., Skrabski Á., Székely A. (2006a): Az életminőség nemi, életkor szerinti és területi jellemzói a magyar népesség körében. In Kopp M., Kovács M. (szerk.): A magyar népesség életminôsége az ezredfordulón. Semmelweis Kiadó, Budapest, 84-105.

Kopp M., Székely A., Skrabski Â. (2006b): Társadalmi-gazdasági helyzet, aktivitás és életminőség. In Kopp M., Kovács M. (szerk.): A magyar népesség életminősége az ezredfordulón. Semmelweis Kiadó, Budapest, 273-287.

Kristensen, T. S. (1995): The demand-control-support model: methodological challenges for future research. Stress Medicine, 11 (1): 17-26.

Lahelma, E., Martikainen, P., Rahkonen, O., Silventoinen, K. (1999): Gender differences in illhealth in Finland: patterns, magnitude and change. Social Science $\mathcal{E}$ Medicine, 48 (1): 7-19.

Lee, S., Colditz, G.A., Berkman, L. F., Kawachi I. (2004): Prospective study of job insecurity and coronary heart disease in US women. Ann. Epidemiol., 14 (1): 24-30.

Li, J., Yang, W., Cho, S. (2006): Gender differences in job strain, effort-reward imbalance, and health functioning among Chinese physicians. Social Science $\mathcal{E}$ Medicine, 62 (5): 1066-1077.

Macintyre, S., Hunt, K., Sweeting, H. (1996): Gender differences in health: Are things really as simple as they seem? Social Science E Medicine, 42 (4): 617-624.

Mohren, D., Swaen, G., Van Amelsvoort, L., Borm, P. J., Galama, J., M. (2003): Job insecurity as a risk factor for common infections and health complaints. J. Occup. Environ. Med., 45 (2): 123-129.

Petróczi E., Fazekas M., Tombácz Zs., Zimányi M. (1999): A kiégés jelensége pedagógusoknál. Magyar Pszichológiai Szemle, 3: 429-441.

Piko, B. F. (1999): Work-related stress among nurses: A challenge for health care institutions. Journal of the Royal Society for the Promotion of Health, 119 (3): 156-162.

Pikó B. F. (2001): A nővéri munka magatartástudományi vizsgálata: Pszichoszomatikus tünetek, munkahelyi stressz, társas támogatás. Lege Artis Medicine 11 (4): 318-325.

Piko, B. F. (2003): Psychosocial work environment and psychosomatic health of nurses in Hungary. Work \& Stress, 17 (1): 93-100.

Pikó, B. (2006): Burnout, role conflict, job satisfaction and psychological health among 
Hungarian health care staff: A questionnaire survey. International Journal of Nursing Studies, 43 (3): 311-318.

Rahe, R. H., Tolles, R. L. (2002): The Brief Stress and Coping Inventory: A useful stress management instrument. International Journal of Stress Management, 9 (2): 61-70.

Rózsa S., Réthelyi J., Stauder A., Susánszky É., Mészéros E., Skrabski Á., Kopp M. (2006): A Hungarostudy 2002 országos reprezentatív felmérés tervezése, statisztikai módszerei, a minta leíró jellemzói és az alkalmazott kérdőívek. In Kopp M., Kovács M. (szerk.): A magyar népesség életminôsége az ezredfordulón. Semmelweis Kiadó, Budapest, $70-82$.

Rózsa S., Szádóczky E., Füredi J. (2001): A Beck Depresszió kérdőív rövidített változatának jellemzói hazai mintán. Psychiatria Hungarica, 16 (4): 384-402.

Roxburgh, S. (1996): Gender differences in work and well-being: Effects of exposure and vulnerability. Journal of Health and Social Behaviour, 37 (3): 265-277.

Sasváriné Bojtor A., Kóczán Gy. (2001): Munkahelyi terhelés az ápolók körében Mentálhigiéné és Pszichoszomatika, 3 (3-4): 66-71.

Schnall, P. L., Landsbergis, P. A., Baker, D. (1994): Job strain and cardiovascular disease. Annual Review of Public Health, 15: 381-411.

Sverke, M., Hellgren, J., Näswall, K. (2002): No security: a meta-analysis and review of job insecurity and its consequences. Journal of Occupational Health Psychology, 7 (3): 242264.

Swaen, G., Bültmann, U., Kant, I., van Amelsvoort, L. G. (2004): Effects of job insecurity from a workplace closure threat on fatigue and psychological distress. J. Occup. Environ. Med., 46 (5): 443-449.

Theorell, T., Karasek, R. A. (1996): Current issues relating to psychosocial job strain and cardiovascular disease research. Journal of Occupational Health Psychology, 1 (1): 9-26.

Van der Doef, M., Maes, S. (1999): The job demand-control (-support) model and psychological well-being: a review of 20 years of empirical research. Work $\mathcal{E}$ Stress, 13 (2): 87-114.

Williams, K., Kurina, L. (2002): The social structure, stress and women's health. Clinical Obstetrics and Gynecology, 45 (4): 1099-1118.

Zigmond, A. S., Snaith, R. P. (1983): The Hospital Anxiety and Depression scale. Acta Psychiatrica Scandinavica, 67 (6): 361-370.

Köszönetnyilvánítás. A tanulmány az OTKA TS-40889 (2002) és a TS-049785 (2004) pályázatok, valamint az NKFP 1/002/2001 és NKFP 1b/020/2004 támogatásával készült.

Köszönetet mondunk a Hungarostudy munkacsoport tagjainak (Csoboth Csilla, Gyukits György, Hajdú Katalin, Lőke János, Odor Andrea, Réthelyi János, Rózsa Sándor, Skrabski Árpád, Stauder Adrienne, Székely András, Szúcs László), valamint az országos védőnői hálózatnak a 2002. évi felmérés elvégzéséért. 


\section{NECULAI, KRISZTINA - SALAVECZ, GYÖNGYVÉR - STAUDER, ADRIENNE - KOPP, MÁRIA \\ WORKPLACE FACTORS AND PSYCHOLOGICAL WELL-BEING AMONG WOMEN EMPLOYED IN THE FIELD OF EDUCATION AND CULTURE}

The objective of the present study is to analyse the association between psychological wellbeing and five work-related stress factors, that is low job control, lack of co-worker support, job insecurity, dissatisfaction with the job and with the supervisor. Methods: The analyses were conducted on a sub-sample of the Hungarostudy 2002 nation-wide representative survey, among the women that were employed in the education and culture sectors $(n=451)$. Psychological well-being was analysed along four indicators: depressive symptomatology, vital exhaustion, anxiety and general well-being. Statistical analysis of the data was performed using stepwise linear regression. Results: Job control proved to be a protective factor for general well-being, while dissatisfaction with the supervisor was related to vital exhaustion and depressive symptomatology and poorer general well-being. Job dissatisfaction predicted all of the four analysed indicators of mental health. Job security was inversely related to anxiety and directly to good general well-being. Unexpectedly, an inverse association between co-worker support and general well-being was found. Conclusions: The results of the study partly support the previous knowledge regarding the association between work-related factors and mental health. Studies like this may stand as starting points for the design and implementation of stress management programs.

Keywords: work-related stressors, mental well-being, women 